\title{
Projekt kuratorsko-artystyczny FEMININE / kobieca kunstkamera
}

\author{
Katarzyna Lewandowska \\ Katedra Historii Sztuki i Kultury \\ Uniwersytet Mikołaja Kopernika w Toruniu \\ cswkasia[]gmail.com \\ Przyjęto: luty 2015; zaakceptowano: czerwiec 2015; opublikowano: lato 2015.
}

\section{Kilka słów wprowadzenia}

(...) mówię swoim ciałem nie wiedząc o tym. Mówię więc zawsze więcej, niż o tym wiem ${ }^{74}$

Prezentuję twórczynie należące do autorskiego projektu kuratorskoartystycznego FEMININE ${ }^{75}$, który odbywa się od roku 2011 w Galerii Wozownia w Toruniu. Cztery wystawy miały miejsce w Galerii Dworzec Zachodni w Toruniu, w roku 2014 wystawy znowu powróciły do Galerii Wozownia. Projekt ten to swego rodzaju nieprzerwanie trwająca interwencja. Cykl osadzony głęboko w konkretnych, zdawałoby się już przepracowanych na gruncie artystyczno-kulturowo-społecznym ideach związanych ze sztuką feministyczną, kobiecym doświadczeniem uwikłanym w ciało, biologię i emocje. Wszystkie artystki biorące udział w FEMININE zostały zaproszone do projektu z kilku ważnych dla mnie powodów. Przede wszystkim kierowałam się subiektywnym, indywidualnym wyborem oraz moimi preferencjami estetycznoetycznymi. Zależało mi również na tym, aby twórczynie nie należały - z różnych przyczyn - do mainstreamowego nurtu sztuki. I właściwie ta charakterystyka stanowiła klamrę zamykającą moje poszukiwania.

\footnotetext{
${ }^{74}$ Jacques Lacan, cytat za: katalog wystawy Nie patrz prosto $w$ stońce 27.06-13.09.2009, Prace z kolekcji Daros Latinamerica, CSW w Toruniu, kuratorki: Agnieszka Pindera, Joanna Zielińska, Toruń, s. 5.

${ }^{75}$ W tym artykule nie uwzględniłam dwóch ważnych ekspozycji: Jaśminy Stasiak Gloomy strangers and nightly experiences (10.04-11.05.2013) oraz Eweliny Kamińskiej Emilia (13.06-30.06.2013). Pominięcie obu wystaw spowodowane jest przygotowywaniem oddzielnej publikacji, w której znajdą się obie artystki.
} 
Poniższe charakterystyki wystaw stanowią krótkie, osobiste impresje, które powstawały przy pierwszym zetknięciu się z pracami artystek. Poniższy wywód ma formę notatnika $\mathrm{z}$ ważnymi zapiskami, stanowiącymi bazę dla przyszłych głębszych, naukowych analiz.

Każda z prezentowanych kobiet-artystek jest silną osobowością, każda z nich wyraża się poprzez różne media i w końcu każda z nich „szepcze do ucha” oglądającego zaklęty szyfr, w swoim języku, który stanowi ważną i zdecydowaną wykładnię „banalnego” i „szarego” życia - tak często ignorowanego i deprecjonowanego przez mężczyzn. Tę kobiecą opowieść można opisać poprzez teorie feministyczne czy też postfeministyczne - i wydają się one jak najbardziej w tym przypadku uzasadnione i pożądane. Stosując te optyki, działania artystyczne poszczególnych twórczyń zostają osadzone w pewnym ciągu tradycji, której początek przypada na przełom lat 60. i 70. w Stanach Zjednoczonych. Silnie umocowana w strukturach akademicko-społecznych, rozpoczyna z impetem walkę o sprawiedliwość - w każdej dziedzinie ludzkiej działalności. W tym okresie widoczne są przede wszystkim dwie przeciwstawne sobie idee: esencjalistyczna i konstrukcjonistyczna ${ }^{76}$, przez które można opisać twórczość przedstawionych poniżej artystek.

Esencjalizm koncentrował się na poszukiwaniu prymarnej, kobiecej podstawy, która byłaby wspólną charakterystyką dla wszystkich istot płci żeńskiej. Diane Fuss (1989) jedna z myślicielek związana z tym światopoglądem - postrzegała esencjalizm jako wiarę $\mathrm{w}$ rzeczywiście prawdziwą esencję rzeczy, niezmienne i ustalone właściwości, które definiują „to, czym jest” danej istoty. Inne badaczki z tego kręgu, takie jak Mary Daly (1973; za: Jakubowska 2002) czy Elizabeth Gould Davis (1971; za: Jakubowska 2002), próbowały za wszelką cenę wydobyć i gloryfikować „to coś wspólnego i ważnego” dla kobiecej natury. Analizując historię człowieka, doszły do wspólnej tezy, że we wczesnych kulturach jedyną panującą władczynią była Wielka Kobieta / Wielka Matka, archetypiczna figura rodząca i jednocześnie pożerająca cały wszechświat. Powołując się na Johanna Jakoba Bachofena (1861/1993) i Carla Gustava Junga (1992) - dwóch najistotniejszych badaczy w wyżej zakreślonym kontekście wyraźnie można wyodrębnić trzy fazy rozwoju tego archetypu w dziejach ludzkości:

1. W pierwszej fazie Bogini Matka panuje niepodzielnie w wyobrażeniach mitycznych człowieka, a męskość ujawnia się w postaci podporządkowanego jej młodego boga.

2. W drugiej fazie tego procesu - przejściowej fazie patriarchalnego buntu mężczyzn - młody bóg emancypuje się stopniowo (choć nieraz gwał-

\footnotetext{
${ }^{76} \mathrm{O}$ tych dwóch ważnych ideach pisałam w: Lewandowska 2014, ale wydaje mi się, że w kontekście prezentowanych artystek są one uzasadnione.
} 
townie) spod władzy Bogini Matki i wraz z innymi bogami męskimi tworzy pod własną egidą (henoteizm) patriarchalny panteon politeistyczny.

3. W trzeciej fazie tego procesu - fazie całkowitej hegemonii patriarchatu — młody bóg „dojrzewa”, „osiąga dorosłość”, stając się z reguły bogiem jedynym, bezceremonialnie strącając boginię do podziemi.

Ten sposób widzenia odpowiadał wyżej wymienionym badaczkom i stanowił mocny argument wobec krytyki patriarchatu. Naczelną postacią w tym dyskursie była Magna Mater. Jak istotny był ów archetyp, zaświadcza chociażby cytat z Krytycznego stownika analizy jungowskiej: „Wielka Matka to wytworzony w zbiorowym doświadczeniu kulturowym ogólny obraz, który wpływa na samoświadomość jednostki” ( Samuel i Shorter i Plaut 1994: 220). Wspólne doświadczenie, wyłącznie zrozumiałe przez kobiety, spowodowało wyraźne podkreślanie różnic między męskim a żeńskim. Nastąpiła bezkompromisowa krytyka logocentryzmu, fallocentryzmu oraz fallologocentryzmu. Narodził się nowy język - ecriture feminine $e^{77}$ : mowa związana z kobiecym ciałem i kobiecą seksualnością. Słowa lepkie, bezwstydne i duszne, szeptem wykrzyczane do ucha, miały wdzierać się pod skórę - głęboko i boleśnie. Uwodzicielsko. „Dlaczego nie piszesz? Pisz! Pisanie jest dla Ciebie, ty jesteś dla siebie, twoje ciało jest dla ciebie, weź je!” (Cixous 1993).

Wolna - bez kulturowego gorsetu, który nie pozwalał jej oddychać, nieokiełznana, silna i nieobliczalna. To Wielka Kobieta, Wielka Matka, Dzika Kobieta Szamanka, Mistyczka, Histeryczka, Wariatka ${ }^{78}$. Nie ma w niej niczego stabilnego, niczego, co odwoływałoby się do racjonalności. Cała jest szyfrem, tajemnicą, splątaną nicią. Ma moc rodzenia, to dobra i zła matka:

Biegun pozytywny zbiera takie cechy, jak matczyna troskliwość i współczucie; magiczny autorytet żeńskości; mądrość i duchowy zachwyt, które przerastają rozum; instynkt czy impuls opieki; wszystko, co jest łagodne, wszystko, co pielęgnuje i podtrzymuje, co przyspiesza wzrost i płodność. Krótko mówiąc - dobra matka. Negatywny biegun przywodzi na myśl złą matkę: wszystko, co tajemne, ukryte, ciemne; otchłań, świat zmarłych, wszystko, co pożera, uwodzi i truje oraz wszystko to, co jest przerażające i czego nie da się uniknąć, jak losu (Jung 1968).

Drugą tendencją, która stoi w opozycji do wyżej opisanej, jest idea konstrukcjonistyczna, mająca swoje początki w słynnej maksymie Simone de Beauvoir: „Nie rodzimy się kobietami - stajemy się nimi” (2003). Kobieta podlega / nie podlega opresyjnym normom, które wymuszają na niej takie a nie inne zachowanie. Kultura (męskość) tresuje i zmusza Naturę (kobiecość) do wchodzenia w określone dla niej przypisane role. Ale jednocześnie ma wybór, mo-

\footnotetext{
${ }^{77}$ Specyficzny język, którego głównymi cechami są: erotyzm, cielesność, nieciągłość, intertekstualność.

${ }^{78}$ Te figury bardzo chętnie wykorzystuje sztuka współczesna (m.in. Carolee Schneemann, Anna Baumgart, Alamagul Manlibayewa, Izabela Ołdak, Mona Hatum, Yvonne Reiner, Orlan, Tejal Shah, Veronika Bökelmann, Zoe Beloff, Katarzyna Swinarska).
} 
że decydować, nie jest już bezwolną istotą, która w imię tradycji (męskiej) żyje w raz ustalonym i niezmiennym kanonie. Kate Millet, Shulamith Firestone, TiGrace Atkinson w swoich badaniach wskazały na fałszywy obraz kobiety preferowany przez esencjalistki. W kształtowaniu tożsamości, „ja”, radykalnie odrzuciły biologiczny determinizm (sex) na rzecz kulturowego wychowania (gender). Krytycznie przeanalizowały przyczyny opresji obecne w systemie patriarchalnym, określającym relację między płcią biologiczną a płcią kulturową. Zgodnie stwierdziły, że sex nie przekłada się na gender (Millet 1982; za: Hołówka 1982: 58-111; Firestone 1971; za: Jakubowska 2002: 17; Davidson 1969).

\section{Prezentacja wystaw poszczególnych artystek}

\section{Ania Lucid ${ }^{79}$ - Feminine}

16.09-09.10.2011, Wozownia

Ania Lucid rozpoczyna cykl FEMININE, nadając swoim pracom taki sam tytuł. Fotografie, które artystka zaprezentowała, odmitologizowują intymne, wyidealizowane portrety kobiece. Prawdziwość Feminine szokuje swoją naturalnością i intymnością. Powszedniość porannej chwili aż boli - w dosłownym tego słowa znaczeniu. Bohaterki na dziewięciu tryptykach są tak (nie)zwykle. Ich ciała mają jeszcze ten specyficzny, lekko ciężkawy zapach snu, są na wpół rozebrane, w domowych pieleszach - przestrzeni związanej z intymnością i brakiem wstydu. Bez żadnego udawania przed sobą i nikim innym, bez uwodzenia kogokolwiek zakładają majtki, stanik, rajstopy. Zaciągając się porannym papierosem, pijąc kawę, poprawiając poły kolorowego szlafroka, czują się szczęśliwe i wolne. Nie ma żadnego świdrującego oka, które bacznie obserwuje. Nie ma opresora, bezwględnie oceniającego. Te kobiety nie muszą nikomu się podobać - choć pewnie za moment sytuacja diametralnie się odmieni, kiedy przekręcą klucz w drzwiach i wyjdą na ulicę. Kobiety Ani Lucid tożsame są z brakiem, emocją, mową, ciałem, skomplikowaniem i przypadkowością, naturalnością, wolnością. Fotografując kobiety w codziennych sytuacjach, artystka skupiła się głównie na powtarzanych działaniach, wykonywanych każdego dnia, na pokazaniu ich jakby zamrożonych w ruchu, wybierając kadry niemożliwe do zarejestrowania przez ludzkie oko. Poprzez zabieg formalny - nałożenie na siebie dwóch obrazów - tego sprzed chwili i tego, co w tym momencie - artystka podkreśla swego rodzaju rozedrganie kobiety. To przesunięcie z jednej strony nadaje fotografiom niezwykłej poetyki, jakiegoś umetafizycznienia banalności i codzienności, z drugiej zaś w prosty sposób

\footnotetext{
${ }^{79}$ Urodzona w Gdańsku, absolwentka Wydziału Sztuk Pięknych Uniwersytetu Mikołaja Kopernika i Szkoły Filmowej w Łodzi. Zwyciężczyni konkursu Viva Foto Awards w kategorii Portret. Zajmuje się fotografią artystyczną i portretową.
} 
opisuje sytuację naruszania stabilnego „ja”. Jednak czy tożsamość musi być ustabilizowana? - retorycznie pyta Jacques Derrida. Artystka stanowczo odpowiada: nie musi.

Sposób prezentacji zdjęć składających się na cykl FEMININE nawiązuje do ostatnich fotograficznych doświadczeń Ani Lucid. Artystka odważnie eksperymentuje $\mathrm{z}$ animacją poklatkową, dezintegracją obrazu fotograficznego oraz inspiracją wideo.

\section{Ania Lucid, Femininie}

(fot. $\mathrm{z}$ archiwum autorki)
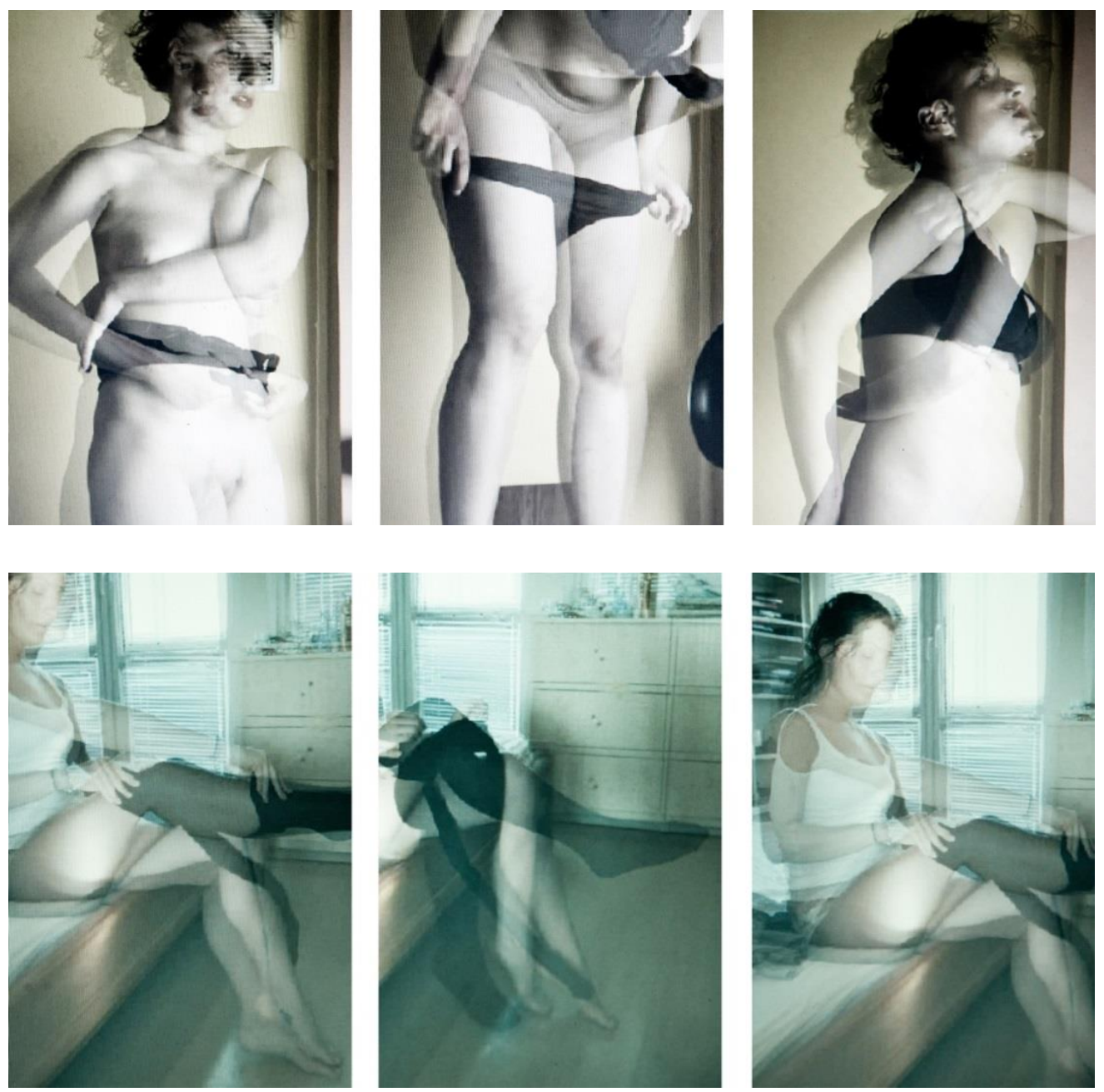


\section{Monika Mausolf - From F. Stories ${ }^{80}$}

\subsection{1-27.11.2011, Wozownia}

From F. Stories to cykl rysunków, które przedstawiają pozornie odrębne historie. Jednak układają się one w całość, opowieść niepokojącą i zaskakującą, w którym głównym wątkiem staje się kobieta, szamanka, wariatka. Nie ma w niej niczego stabilnego, niczego, co odwołuje się do racjonalności i rozumu. Ona jest rozchwiana - a tym samym niebezpieczna, bo nieobliczalna. Zamieszkuje miejsca przerażające, doskonale czuje się na cmentarzach, w gęstych lasach lub na bagnach. Biega boso, by czuć ziemię pod stopami. Niszczy, by budować, zabija, by rodzić, zabiera, by dawać. Tożsama z tym, co zwierzęce, dzikie, instynktowne, cielesne. Dla Niej nie ma żadnych nakazów ani zakazów, jest dynamiczną, silną energią, która pojawia się między jawą a snem, szepcząc bezeceństwa, w których ukryta jest mądrość. Cała jest szyfrem, tajemnicą, splątaną nicią.

Tytuł tego cyklu nawiązuje do życia dwóch wyjątkowych kobiet: Barbary Urselin - owłosionej „kreatury”, budzącej pożądanie, wstręt i strach - oraz błogosławionej Katarzyny Tekakwitha - Irokezki z wojowniczego plemienia Mokhawków, Indianki o twarzy pełnej głębokich blizn po przebytej w dzieciństwie ospie. Pierwsza to młoda dziewczyna, która posiadała niezwykle bujne owłosienie, traktowane przez właścicielkę z najwyższym ubóstwieniem. Swoje piękne ciało przykrywała białym prześcieradłem z otworem na podbrzusze i łono. Nad pępkiem, który przeistaczał się w nos, malowała oczy, a włosy łonowe, niczym brodę starca, rozczesywała na dwie części, tak aby widoczne były wargi sromowe: usta wypowiadające święte słowa. Natomiast Katarzyna stała się bohaterką obrazoburczej powieści Leonarda Cohena Piękni przegrani. Maniakalny pan F. podąża śladami swojej patronki, oddając jej szczery kult. Pragnienie jest tak silne, że mężczyzna popada w niebezpieczną obsesję „schwytania” Tej, której nie da się schwytać.

Fascynacja artystki światem roślinnym, groźną, niezwykle seksualną naturą, pełną odniesień do kobiecej fizjonomii i cielesności, doprowadziła do stworzenia Źródła - obiektu kojarzącego się z drzewem. Mausolf nadała staremu, męskiemu symbolowi cechy kobiece. Jego falliczny kształt ginie pośród bruzd, które przypominają swoją formą waginy, a to, co z nich wypływa, to kobiece, życiodajne soki.

\footnotetext{
${ }^{80}$ Absolwentka Wydziału Sztuk Pięknych oraz Katedry Historii Sztuki i Kultury Uniwersytetu Mikołaja Kopernika. Dyplom obroniła z wyróżnieniem na kierunku Malarstwo. Uprawia malarstwo, rysunek, tworzy obiekty. W swojej twórczości skupia się przede wszystkim na strukturze i materii. Interesuje ją człowiek, uprzedmiotowienie ciała w kulturze oraz szeroko pojęta sztuka feministyczna.
} 


\section{Monika Mausolf, Upsowienie}

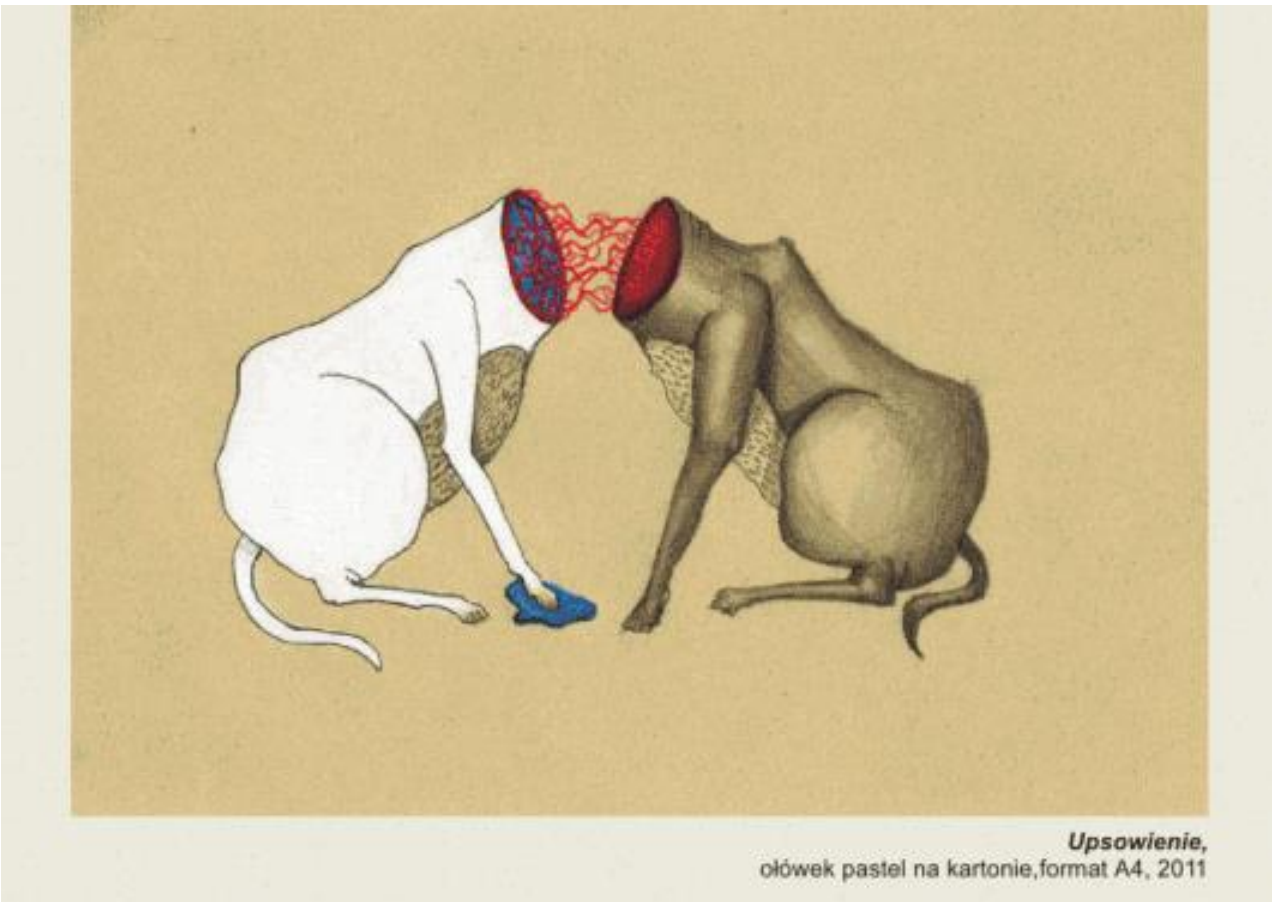

Monika Mausolf, Portret Barbary

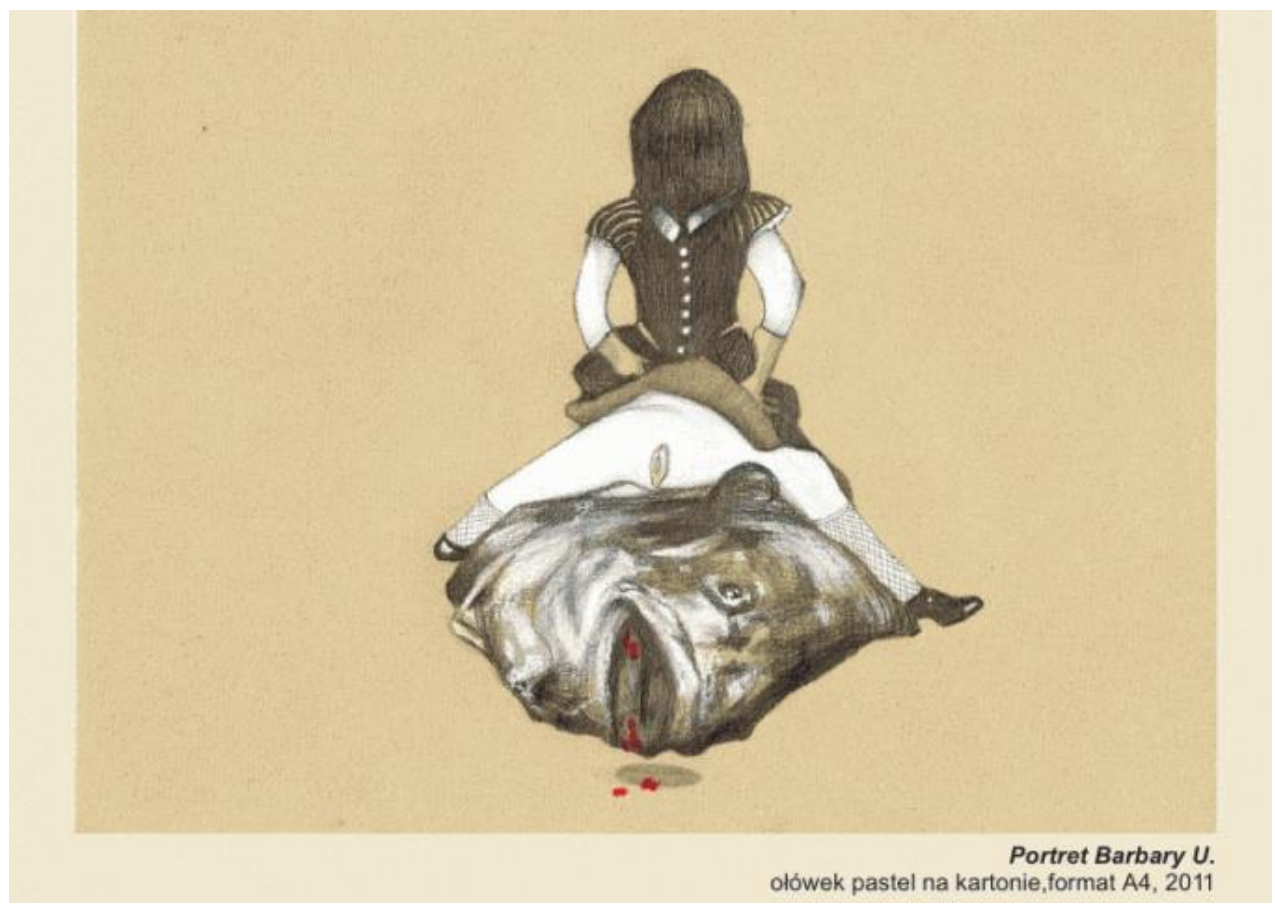

(fot. $\mathrm{z}$ archiwum autorki) 


\section{Adriana Lisowska ${ }^{81}$ - (Nie)winne marzenia}

16.12.2011-08.01.2012, Wozownia

(Nie)winne marzenia bezwstydnie zapraszają do perwersyjnego świata kobiecych fantazmatów - banalnych, szalonych, ekstatycznych, niebezpiecznych i wciąż stabuizowanych. Artystka raczy widza kobiecością odartą z wszelkich niuansów i niedopowiedzeń, lepki język staje się dosłowny. Szeptem wykrzyczanym do ucha, uwodzicielsko biegnie dalej, wbijając się głęboko i jeszcze głębiej. Bez metafor i zbędnych porównań zadaje niezwykle trudne pytania. Wstydliwe, intymne, duszące, ale jakże potrzebne. Artystka okrutnie traktuje oglądającego (siebie samą także) stawiając go pod ściana, spod której nie ma ucieczki. Adriana w swoich obiektach i fotografiach wykorzystuje dawne pejoratywne charakterystyki siebie, nadając im pozytywne znaczenia. To, co było odrzucone i traktowane przez męski świat jako nieistotne, codzienne, nudne i śmieszne, w prezentacji artystki zyskuje całkowicie inną wartość. To, co dawniej było odrzucone i traktowane przez optykę męską jako nieistotne i banalne, w pracach Lisowskiej zyskuje zupełnie inną wartość. Te określenia zostają przedefiniowane, na nowo odczytane i odkryte.

Mała, uzębiona wagina zamknięta zostaje w klatce, jest czymś kuriozalnym, pociągającym, a zarazem przerażającym. Erotyczne skadrowane fotografie wizualizują seksualne fantazmaty kobiet skierowane na inne kobiety. Każda z wagin jest kwiatem, reprezentującym różne gatunki i odmiany. Usytuowane na fragmentach nagich, kobiecych ciał, stanowią centrum przedstawienia. Catherine Blackledge pisze:

Siedlisko rozkoszy (wagina), „miejsce poczęcia”, droga, którą przechodzimy na świat - a zarazem organ, o którym wiemy tak niewiele, mniej niż o innych częściach ciała ludzkiego. Dlaczego tak się dzieje. (...) Waginie przypisywano niegdyś moc magiczną: jej obnażenie miało poprawić urodzaj i odpędzić zło; potem uznano ją za narzędzie szatana, wreszcie za bierne naczynie, w którym dojrzewa nowe życie. Podejście do kobiecej seksualności uległo zatem diametralnym zmianom, a długo pokutujące przesądy sprawiły, że pewne aspekty funkcjonowania żeńskich narządów płciowych nadal pozostają niewyjaśnione (2005).

Zaś Lucy Irigaray w sposób następujący przedstawia „historię” tego ambiwalentnego narządu kobiecego: „Macica, nie przemyślana jako miejsce pierwszego przebywania, gdzie stajemy się ciałem, przekształca się dla wielu mężczyzn w fantazmat pożerających ust, kloaki albo upustu analnego lub moczowego, w falliczne zagrożenie, a w najlepszym razie w reproduktorkę” (zob. Kowalczyk 2002).

\footnotetext{
${ }^{81}$ Zajmuje się rzeźbą, fotografią i biżuterią eksperymentalną. Dyplom z wyróżnieniem uzyskała na Wydziale Tkaniny i Ubioru Akademii Sztuk Pięknych w Łodzi. Laureatka konkursów z zakresu biżuterii artystycznej. Od 2007 roku współtworzy grupę projektową LIS2. Jej prace znajdują się m.in. w zbiorach Muzeum Bursztynu w Gdańsku. Mieszka w Gdyni.
} 
Odwołując się do optyki komparatystycznej, która w tym szczególnym kontekście wydaje się bardzo ciekawa, ale i pomocna, należałby przyjrzeć się „waginalności” i jej symbolice w tradycji buddyzmu wadżrajany. Tam wagina urasta do samoistnej, autonomicznej zasady równorzędnej z pierwiastkiem męskim. Interesująca jest idea Tathagatagharby (skt. Tathagathagabha), kosmicznej macicy, która zostaje wyniesiona do fundamentalnej zasady oświecenia.

Adriana Lisowska, Niewinne marzenia
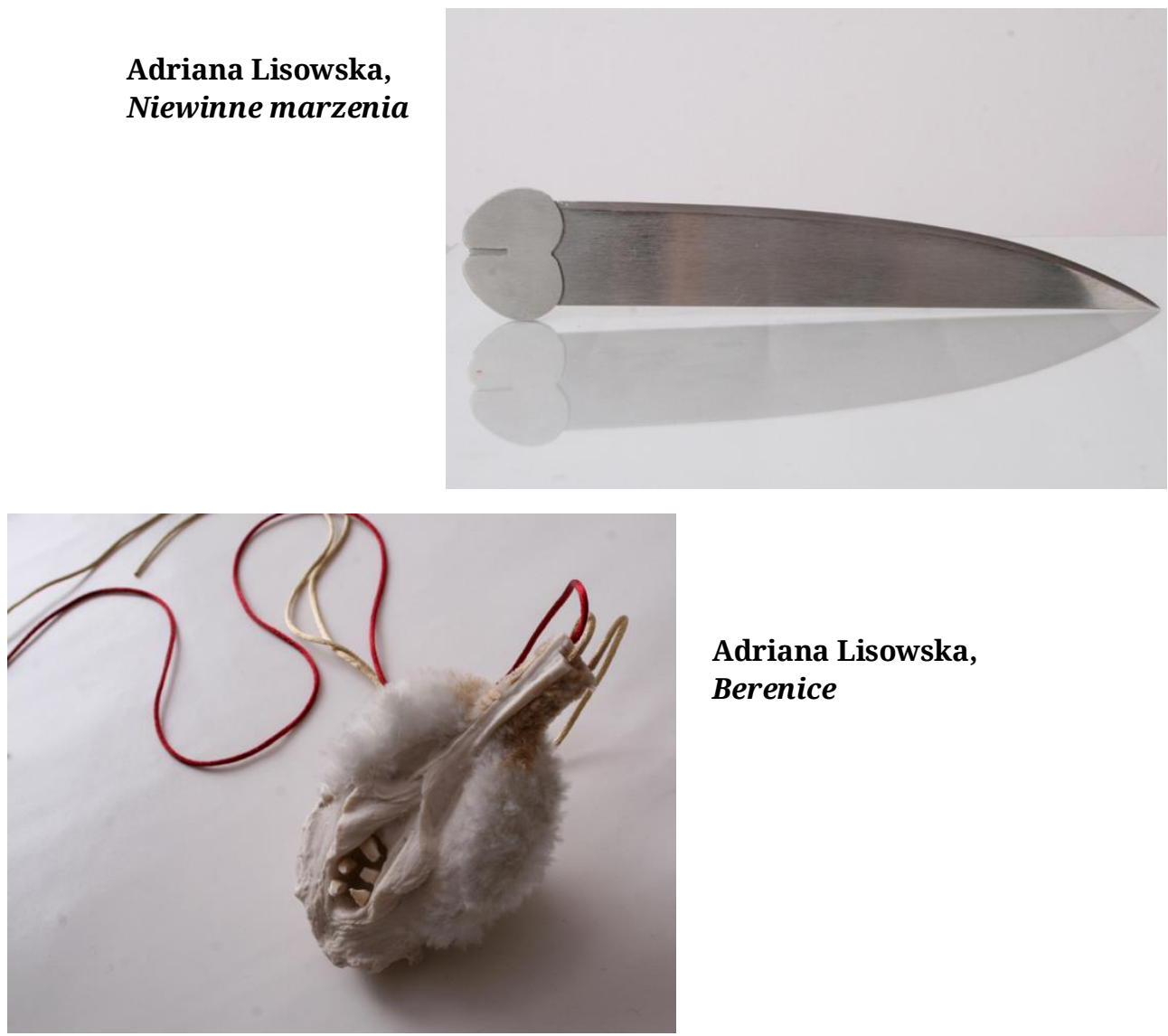

Adriana Lisowska, Berenice

Adriana Lisowska, Always Fresh

(fot. $\mathrm{z}$ archiwum autorki)






\title{
Sylwia Galon ${ }^{82}$ - Eskalacja
}

09.03-08.04.2012, Wozownia

\author{
Forma jest pustka \\ Pustka jest forma \\ Forma nie różni się od pustki \\ A pustka od formy
}

(zob. Gesche Rabten 1982: 18)

Eskalacja Sylwii Galon za chwilę wedrze się w naszą bezpieczną (?) przestrzeń, zassie to, co dookoła. Ta potężna energia za moment zniszczy wszystko, co będzie stanowiło dla niej jakąkolwiek przeszkodę. Ale pokaleczy również siebie. Nienaruszalna forma zginie, stanie się czymś zupełnie Innym, rozszarpaną kreaturą, po której zostaną bezkrwawe strzępy. Proces niezwykły, pełen napięcia, przymusu, dynamicznego wzrostu i pęknięcia. Ale jest to również proces konieczny, oczyszczający. Po wybuchu następuje cisza, potem słychać pojedyncze głosy, następnie gwar, szum i hałas. I znowu dochodzi do wybuchu. Artystka o swojej pracy mówi:

Do tytułowej Eskalacji dochodzi w momencie przeładowania, przekroczenia pewnej granicy. Powstaje, gdy struktura poddaje się wewnętrznemu napięciu i ulega pęknięciu. Wybuch, który zwykle trwa ułamek sekundy, w instalacji jest rozciągniety w czasie. Patrząc na pracę widzimy zatrzymanie akcji. Wybuch dokonuje się do pewnego momentu, to niedopełnienie rozpoczętego działania nadaje pracy uśpioną dynamikę. Budzi ona podobne odczucia jak obraz Davida Hockneya, przedstawiający rozpluskującą się wodę w basenie po wykonaniu skoku przez niewidocznego bohatera. Nie jest to praca stworzona z myślą o pobudzeniu w odbiorcy określonych odczuć estetycznych, jest raczej prostym podejściem do tematu czasu. Prostym, bo osiągniętym dzięki nieskomplikowanemu zabiegowi przeniesienia czystej, graficznej formy na przestrzenny obiekt, nadając mu tym samym lekko odrealnioną, komiksową estetykę ${ }^{83}$,

Eskalacja to instalacja site-specific opracowana dla przestrzeni Archiwum w Wozowni.

\footnotetext{
${ }^{82}$ Urodzona w 1986 roku. Zajmuje się głównie wideo, instalacjami, działaniami multimedialnymi, bioartem. Absolwentka Akademii Sztuk Pięknych w Gdańsku, studiowała również w Dutch Art Institute w Holandii. Artystkę interesują działania zarówno postkonceptualne, jak i sztuka zaangażowana, redefinicje, tworzenie nowych kontekstów. Mieszka i pracuje w Gdańsku.

${ }^{83}$ Źródło: URL = <http://wozownia.pl/exposureid184-28,26-Sylwia_Galon_-_Eskalacja >.
} 
Sylwia Galon, Eskalacja

(fot. Michał Jaskólski)



\section{Anna Pilewicz ${ }^{84}$ - Klitoridektomia}

\subsection{4-06.05.2012, Wozownia}

Klitoridektomia Anny Pilewicz jest okrutna i niepokojąca. Artystka perfekcyjnym cięciem chirurgicznego noża zagłębia się w żywe ciało kobiety. Poprzez odwołanie się do brutalnego, afrykańskiego rytuału projekt staje się wieloznaczny, pełen odniesień, bólu i prawdy. Artystka zwraca uwagę na okrucieństwo oraz upokorzenie wynikające $\mathrm{z}$ tego zabiegu, efekt bezrefleksyjnie przyjmowanej ideologii, która dla kultury europejskiej zdaje się być zupełnie absurdalna. Ale czy rzeczywiście? Odpowiedź jest tak samo bolesna jak ten krwawy zabieg. Klitoridektomia ewokuje wszelkie negatywne zjawiska towarzyszące patriarchalnej: przemoc, hierarchizację, nadużywanie władzy, racjonalizowanie (wobec kobiety, ciała, nieopisanego/nieoswojonego, skomplikowania, przemieszczenia, przypadkowości). Na Zachodzie jest to przemoc niejednokrotnie bardziej zawoalowana i nie zawsze przybierająca formę bezpośredniego przymusu. Czasem nie staje się tak oczywista, a często jest wręcz ukryta. Klitoridektomia w interpretacji Anny Pilewicz to słowo-znak, które bezwzględnie odziera OPRESJĘ z jakiejkolwiek metafory na rzecz okrutnego konkretu.

Klitoridektomia jest projektem interdysyplinarnym obejmującym wideopoezję, wiersze w formie drukowanej oraz grafiki (kolografie).

Artystka na obraz wideo nakłada zgęszczoną, mocną poezję, która mówi o wstydliwych, stabuizowanych aspektach kobiecości. Mówi:

W projekcie krytycznie odnoszę się do wprowadzania w sferę kultury silnie zdominowanej przez fallogocentryzm. Tak uformowana kultura, kumulująca wiele negatywnych zjawisk, w istocie pozbawia wyobraźni. Według Gilberta Duranda w zachodniej kulturze europejskiej dominują „dzienne” układy wyobrażeń z „platońskim rozszczepieniem i kartezjańskim dualizmem”. To, co „dzienne” akcentuje różnice i dąży do ich wyodrębnienia, rozszczepia i geometryzuje; inaczej niż „nocne”, spośród których do najważniejszych można zaliczyć stany wewnętrzności, głębokości czy przemieszania. W projekcie video niektóre z wierszy zawartych w książce wpisane zostały w obraz i wzbogacone o muzykę Magdaleny Głockiej. Przy tworzeniu video wykorzystuję często analogowe techniki, używając diaskopu, szkieł, barwnych płynów i przezroczystych obiektów. Interesuje mnie także efekt synestezji, wzajemnego dopełniania się, przenikania różnych dziedzin sztuki. Pracując nad video, bardzo często nakładam na siebie różne obrazy, dążąc

\footnotetext{
${ }^{84}$ Ukończyła filologię polską na Uniwersytecie Mikołaja Kopernika w Toruniu wraz ze specjalizacją teatrologiczną. Studiowała również literaturoznawstwo na tejże uczelni. Tworzy poezję, malarstwo, grafikę i wiedeo-art. Interesuje ją interdyscyplinarność, między innymi przenikanie się sztuk wizualnych, literatury i muzyki. Przy tworzeniu wideo wykorzystuje często analogowe techniki, używając diaskopu, szkieł, barwnych płynów i przezroczystych obiektów. W jej twórczości malarskiej pojawiają się głównie wizje żywiołów i wizerunki kobiet. Prowadzi swoją autorską galerię w Toruniu: Rekwizytornię Drzew.
} 
do uzyskania złożonej, wielowarstwowej „tkaniny”, dzięki czemu uzyskuję obraz miękki, wielokształtny i efemeryczny ${ }^{85}$.

Anna Pilewicz prezentuje również dwie grafiki: Klitoris i Urizena, bezpośrednio odwołując się do kosmologii Williama Blake’a. Dychotomiczny podział na kobiece i męskie konstruuje cały wszechświat, wyraźnie nadając charatekterystyki obu tym optykom. Urizen jest racjonalny, patrzący swoim boskim okiem, oceniający, związany z siłą i wiedzą. Natomiast wieloręka BoginiKlitoris odpowiedzialna jest za rytuały diwinacyjne, rodzenie i pochłanianie, rozedrganie i przypadkowość, muzykę i Ziemię.

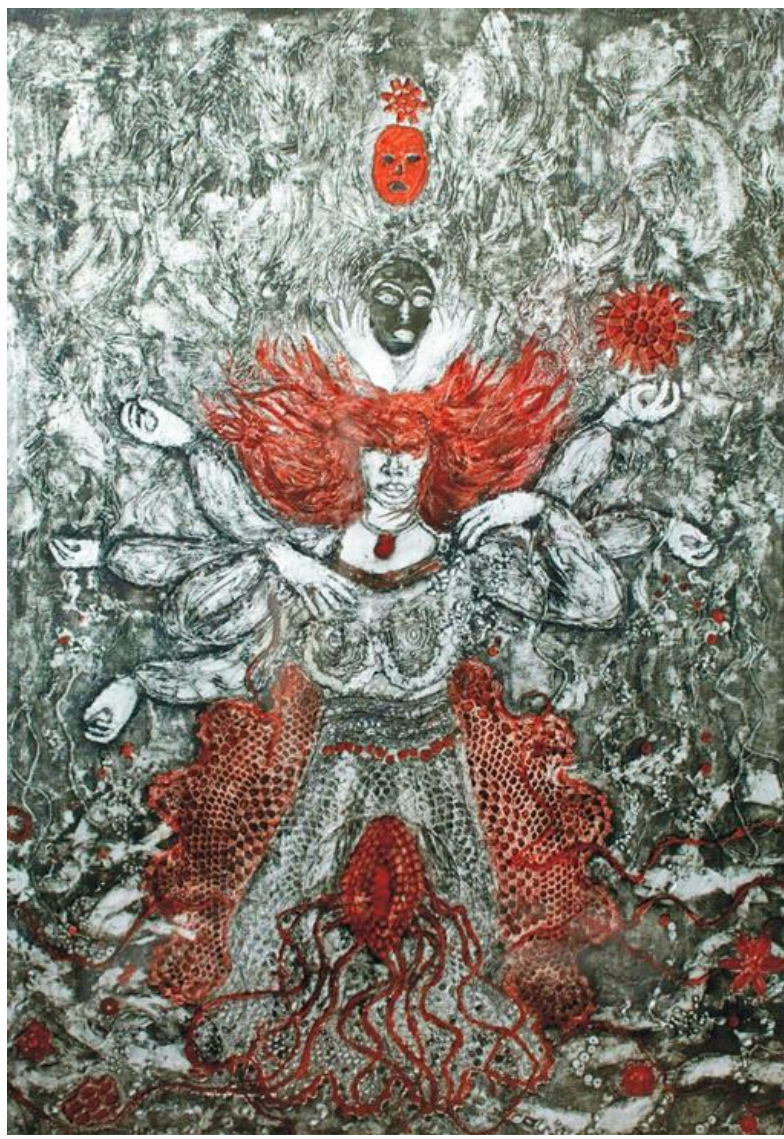

\section{Anna Pilewicz, Urthona-Klitoris z cyklu Klitoridektomia}

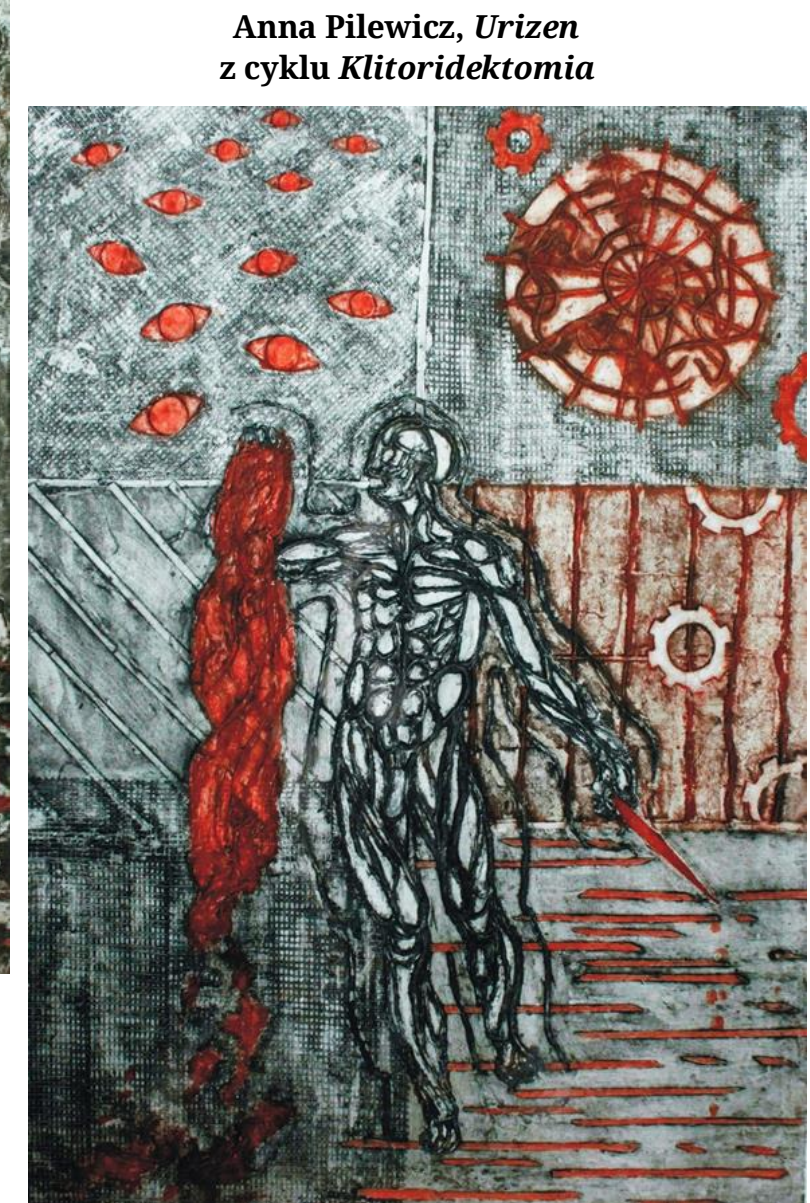

(fot. $\mathrm{z}$ archiwum autorki) 


\section{Maria Kubit ${ }^{86}$ - M(e)rror}

\subsection{5-20.05.2015, Wozownia}

M(e)rror jest wystawą osobistą, pełną intymnych odniesień do trudnych zagadnień egzystencjalnych (życia, przemijania, śmierci). Artystka poprzez tytułowy M(e)rror wprowadza widza w niebezpieczny, ale i fascynujący świat iluzji. Zdeformowana rzeczywistość, odbijająca się w lustrze (znaku, który jednocześnie jest znaczącym - materiałem graficznym, i znaczonym - formą myśli). Tytuł, który poprzez specyficzny zapis oznacza również „błąd” ale i „mnie”/,ja”, zmusza widza do wejścia w tę zafałszowaną przestrzeń i zadania sobie podstawowych pytań związanych z ludzką egzystencją: kim jestem? dokąd zmierzam? czego chcę?

Maria Kubit, prezentując podwójne portrety kobiet (siebie, swojej mamy, babci, siostry), dotyka niezwykle trudnych relacji pomiędzy matkami a córkami. Te kobiety bezpardonowo, przez całe życie walczą o dominującą pozycję. Przepychają się, szarpią, oceniają, obserwując wzajemnie, pełne miłości i nienawiści.

\section{Maria Kubit, Żótty M(E)RROR}

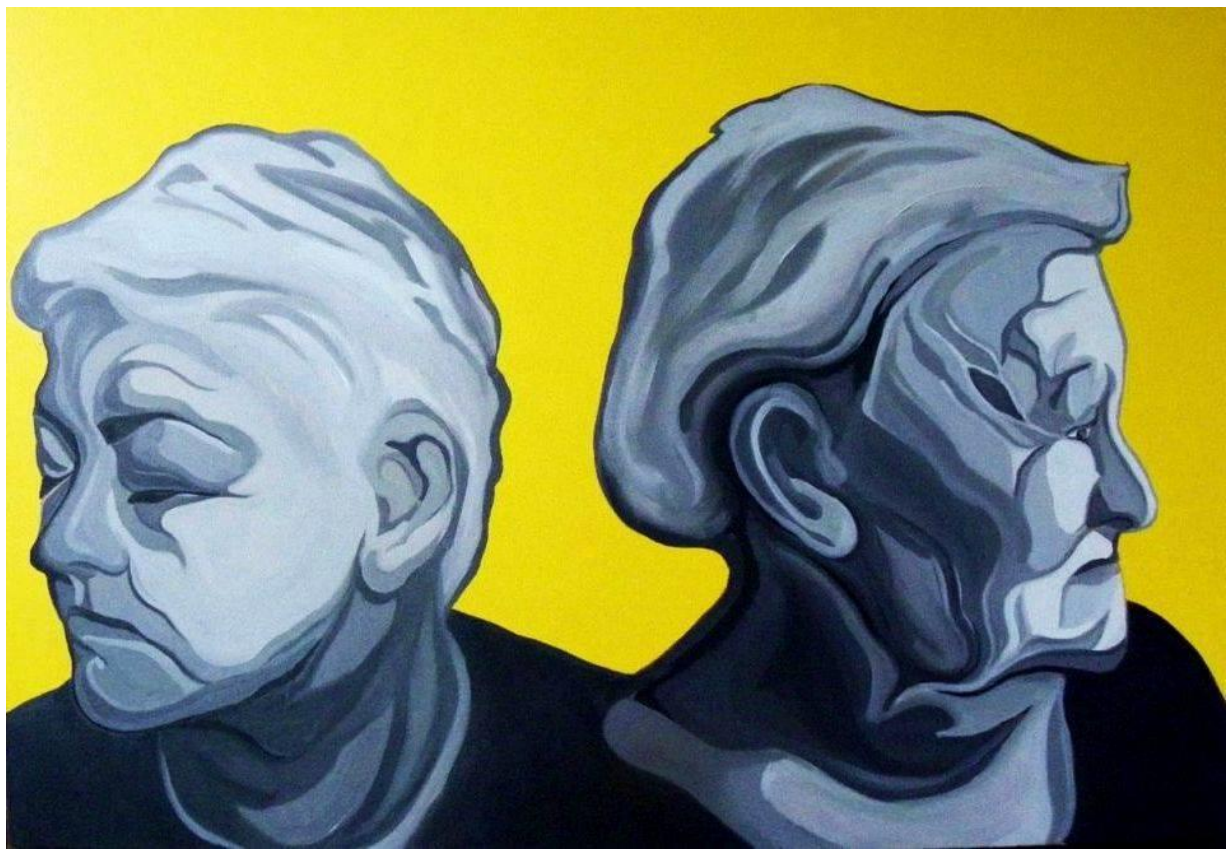

(fot. $\mathrm{z}$ archiwum autorki)

\footnotetext{
${ }^{86}$ Urodzona w 1984 roku w Krośnie, gdzie ukończyła Państwowe Liceum Sztuk Plastycznych im. Tadeusza Brzozowskiego. Absolwentka Wydziału Sztuk Pięknych w Toruniu na kierunku Malarstwo Sztalugowe. W 2009 roku uzyskała dyplom z wyróżnieniem w pracowni Prof. Lecha Wolskiego. Uzyskała również aneks z rysunku oraz malarstwa ściennego.
} 


\section{Martyna Majczuk ${ }^{87}$ - Obrazy Życia / Performans}

\subsection{1-07.12.2012, Dworzec Zachodni}

Martyna Majczuk, tak jak Teresa Margolles w Watercolors, a przed nią Yves Klein w błękitnych Antropomorfiach, zamyka w obrazach człowieka w dosłownym tego słowa znaczeniu. Płótno wsysa w siebie jego cielesność, jego formę, przyjmując przede wszystkim magiczną ciecz, jaką jest krew - tę dobrą i tę złą, czystą i nieczystą, gorącą i zimną, jednak w tym przypadku zawsze kobiecą. Bo „krew jest jak sok niepowszedni” (Goethe 2012).

Artystka igłami ponakłuwała kobietę i cierpliwie wyczekała momentu, w którym nastąpiło najsilniejsze krwawienie, aby móc dokładnie odbić na dziewięciu płótnach jej ciało. Zarysowała mocny kontur krwawiących części ciała: piersi, brzucha, ud, pośladków, dłoni. (Nie)winny obraz powstawał z fragmentów bardzo powoli, stopniowo. Pierwszy całun stanie się swego rodzaju matrycą: bazą do odbicia kolejnych, coraz mniej wyraźnych, aż do zupełnego zniknięcia. W końcu cielesny obraz, nasycony bólem, strachem, wstydem, intymnością, seksualnością, krwią, potem i zapachem kobiety, rozpuści się.

Druga kobieta leżąca w pozycji embrionalnej na wysokim postumencie została zakolczykowana. Poprzez umieszczenie kolczyków w różnych częściach ciała i powiązanie ich transparentną linką kobieta znalazła się w bardzo niekomfortowej dla siebie sytuacji. Najdelikatniejszy ruch sprawiał silny ból i niebezpieczeństwo wyrwania kolczyka z ciała. Ta opresyjna sytuacja definiuje kobietę jako ofiarę - ze wszystkimi tego konsekwencjami. Z drugiej strony odwołuje do filozofii George Bataille, w której padają istotne kwestie, tak często podejmowane przez współczesną sztukę: „Co jest czyste, a co nieczyste?, Odpychające i fascynujące? Co jest erotyzmem, a co sacrum?” I w końcu podsumowanie: „Zbrukanie - najwyższe doświadczenie bytu” (zob. Menninghaus 2009: 415-440).

\footnotetext{
${ }^{87}$ Urodzona 29.09.1986 r. Absolwentka kierunku Ochrona Dóbr Kultury na Wydziale Sztuk Pięknych Uniwersytetu Mikołaja Kopernika (2010). Nagrodzona za pracę magisterską pt. Nagrobki na cmentarzu $w$ Sapancie napisanej pod kierunkiem Prof. dr hab. Jerzego Malinowskiego. Na co dzień prowadzi studio „Bodyfikacje”, spełnia się jako piercerka oraz tatuażystka. Tworzy kontrowersyjne projekty z zakresu sztuki współczesnej, w których głównym medium jest ciało.
} 

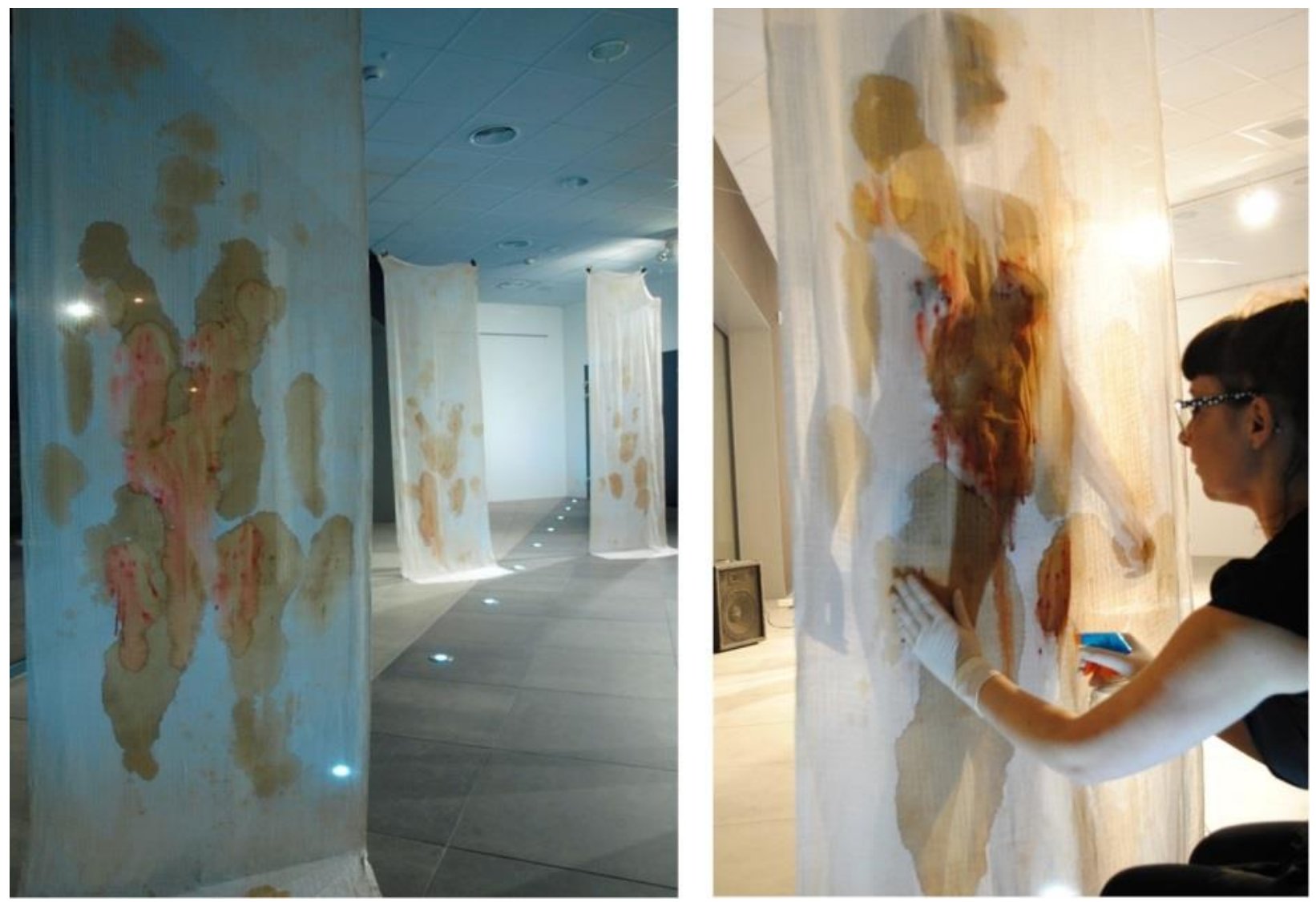

Martyna Tyna Majczuk, Catuny z cyklu Obrazy życia

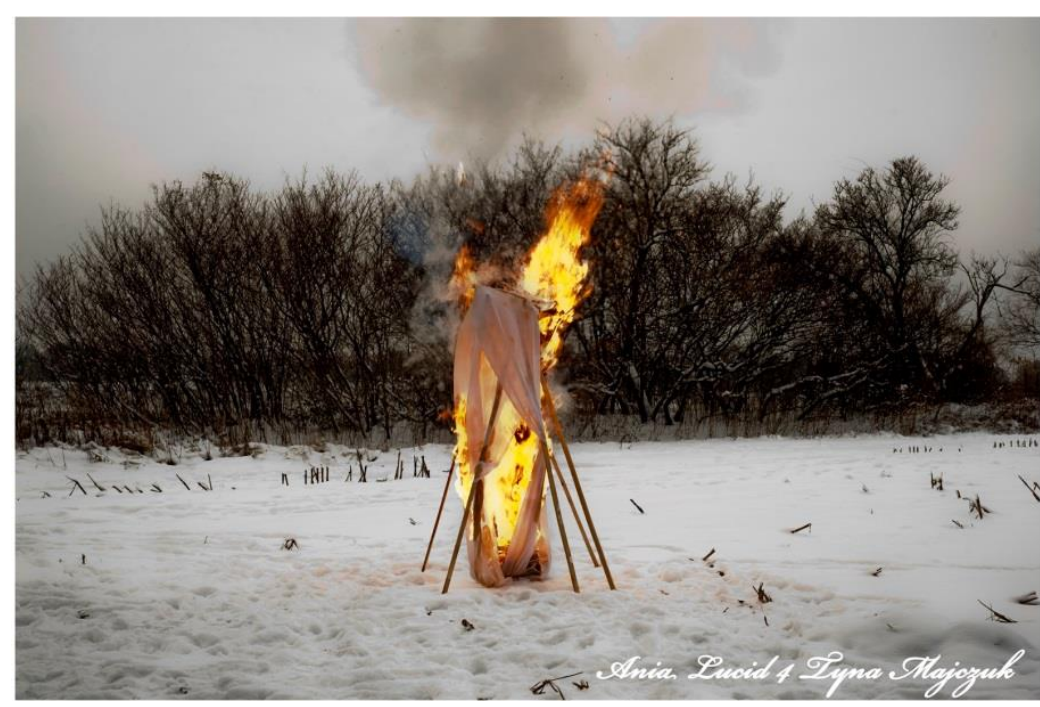

Martyna Tyna Majczuk Żywa rzeźba - ONA

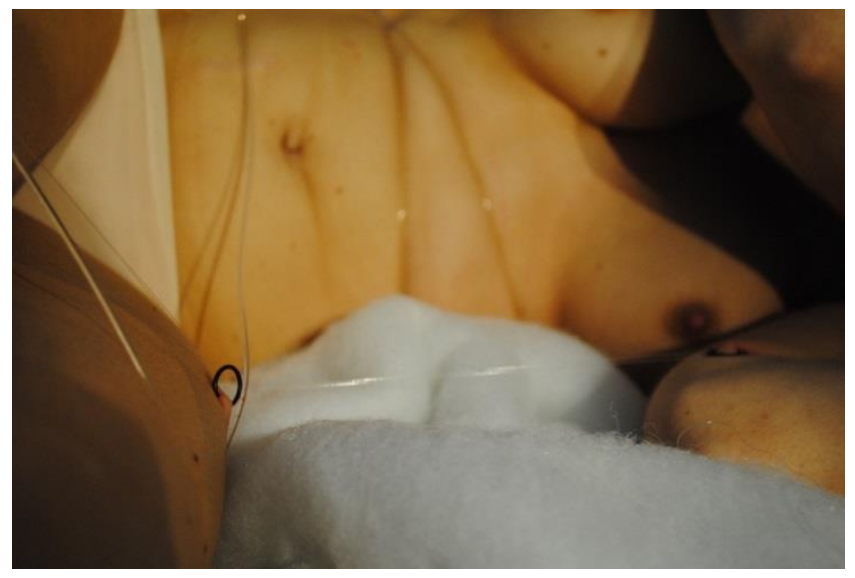

(fot. $\mathrm{z}$ archiwum autorki) 


\section{Urszula Kluz-Knope ${ }^{88}$ - Keep away from fire}

\subsection{1-18.02.2013, Dworzec Zachodni}

Jej perwersyjne, czasem niepokojące fantazmaty wdzierają się głęboko, do wnętrza, rozlewając się niczym zatruta ambrozja - dająca i równocześnie odbierająca życie. Rozkosz szybko zmienia się w ból, a może to właśnie taki rodzaj rozkoszy, którą osiągnąć można jedynie poprzez mocny uścisk na szyi. Artystka czaruje: pojawia się, by na chwilę zniknąć, szepcze, krzycząc, tańczy szaleńczo, nie odrywając swoich nagich stóp od ziemi, milczy, naśladując przeraźliwe głosy natury. Artystka staje się Wielką Kobietą/Matką, Córką, Towarzyszką mężczyzny, Wariatką i Kreaturą.

\section{Urszula Kluz-Knopek Olimpia}

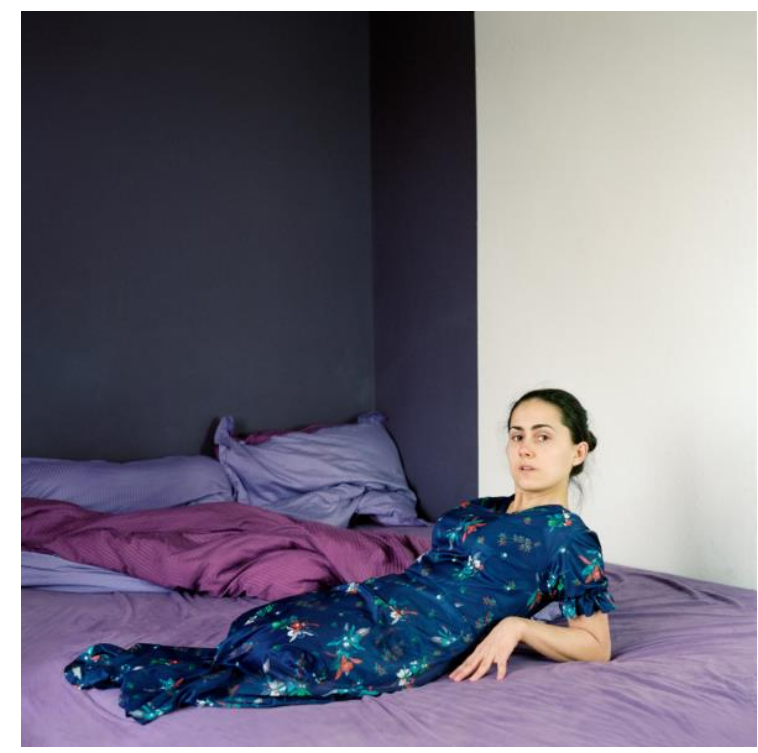

Urszula Kluz-Knopek pokazała fotografie, układając je w swego rodzaju kobierzec, mozaikę, tkaninę, w której poszczególne fragmenty opowiadają Jej historię, uwikłaną w codzienne życie. Wyszywa obrazy, wbija się aparatem jak igłą w materię kliszy. Jedna z artystek południowokoreańskich Kim Sooja mówi w ten sposób:

W punkcie, gdzie igła przebija materiał, możemy połączyć dwa różne brzegi szmatek przy pomocy nici przeciągniętej przez oczko igły. Igła jest przedłużeniem naszego ciała, a nitka rozszerzeniem umysłu. Ślady umysłu zawsze pozostają w

\footnotetext{
${ }^{88}$ Urodzona w 1985 roku w Ustroniu. Artystka intermedialna wykorzystująca w swoich działaniach instalację, wideo oraz fotografię. Szczególnie zainteresowana relacją obiekt-odbiorca, gdzie ten drugi nigdy nie jest wyłącznie obserwatorem. Doktorantka na Wydziale Intermediów Akademii Sztuk Pięknych w Krakowie. Absolwentka Uniwersytetu Artystycznego w Poznaniu oraz inżynier informatyki. Od kilku lat właścicielka graficznego „Studia Bakłażan”. Pracuje również jako mentor w projekcie „Link do Przyszłości dla Fundacji Rozwoju Społeczeństwa Informacyjnego” finansowanego ze środków Microsoftu. Redaktor naczelna magazynu artystyczno-naukowego Woof Woof Arf Arf.
} 
materiale podczas, gdy igła opuszcza pole działania kiedy tylko skończy swoją pracę. Igła jest środkiem, misterium, rzeczywistością, hermafrodytą, barometrem, chwilą i Zen (Furmanik 2007).

W przypadku Urszuli medium jest inne, ale idee są identyczne. Artystka mierzy się z rzeczywistością i wszelkimi aspektami związanymi z ludzkim/kobiecym życiem.

Urszula Kluz-Knopek Cmentarz

(fot. $\mathrm{z}$ archiwum autorki)

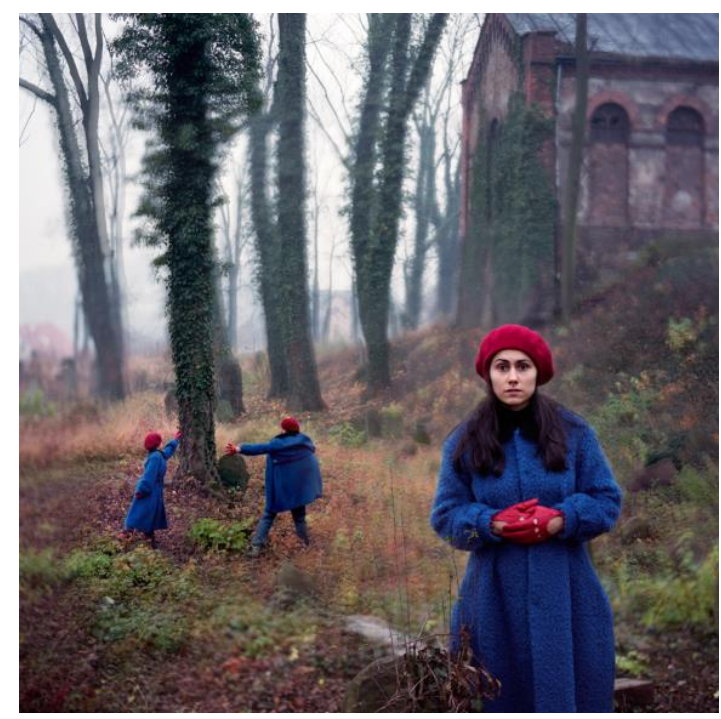

\title{
Urszula Kozak ${ }^{89}$ - Elektrownia Jądrowa w Żarnowcu
}

\author{
09.01. - 08.02.2015, Wozownia
}

Ten niedokończony, związany z opresyjną władzą eksperyment - Elektrownia Jądrowa w Żarnowcu - stanowi dla Urszuli Kozak punkt wyjścia dla niezwykle głębokich i bardzo ważnych kontekstów. Betonowa architektura elektrowni przypomina martwe, okaleczone ciało, które każdego dnia ulega biologicznemu rozkładowi. W tym przypadku kreatura nigdy nie narodziła się, nie zdążyła przybrać ostatecznej formy, pozostała na etapie formowania się szkieletu. Ogołocona z mięśni i skóry, bez krwioobiegu, z życiodajną cieczą i rytmicznie pulsującym sercem, stanowi jedynie przerażający artefakt, który poprzez swoje kalectwo opowiada o sile, nigdy nie wypróbowanej, o niebezpiecznym potencjale ukrywanym w szczelinach tej monumentalnej architektury.

\footnotetext{
${ }^{89}$ Urodzona w 1989 w Londynie, w 2009 ukończyła Liceum Plastyczne w Zakopanem. W latach 2010-11 studiowała Rzeźbę na Akademii Sztuk Pięknych w Gdańsku w pracowni prof. Katarzyny Józefowicz. W 2011 podjęła indywidualny tok studiów w Katedrze Intermediów, łączący elementy rzeźby oraz mediów, zakończony w 2014 pracą dyplomową - projektem Elektrownia Jądrowa Żarnowiec, Re-eksploracja, który został nagrodzony Grand Prix na Festiwalu Sztuki Wizualnej 10. Inspiracje / XTREME w Szczecinie. Artystka współorganizuje wydarzenia promujące wideo-art i wideo-performance $\mathrm{w}$ kraju i za granicą. Obecnie koncentruje się na rozbudowaniu tematu Elektrowni Jądrowej w Żarnowcu, który od 26 września do 12 października 2014 był prezentowany na wystawie Power Plant Glitch w Galerii R46 we Wrocławiu.
} 
Wszędzie woda, a w niej pływająca artystka - cicho penetrująca tę „zarażoną” tkankę. Delikatne, żywe ciało spokojnie (?) przemierza to wielkie cmentarzysko. Ta (nie)rzeczywista rzeczywistość zbudowana jest przede wszystkim z kontrastów, które wymuszają ambiwalentne skojarzenia: życie/śmierć, natura/technologia, czyste/nieczyste. Artystka na zimno, bez zbędnych ozdobników rzuca przed widza jego i innych okrucieństwo wobec natury, która milcząco przyjmuje kolejne uderzenia. Zabawa w naukowców przynosi niebezpieczne i bolące wyrwy w jej ciele. Spalona, zatruta ziemia, skażona trucizną rodzi kalekie, zdeformowane istoty. Okaleczone ciała z okaleczonej matki i z ojca pełnego zawiści, tak bardzo chętnego mordu. Okrutnego, samowolnego zadowolonego z siebie tyrana, który bez żadnego mrugnięcia „boskim okiem” bierze w swoje posiadanie Naturę - gwałci ją w imię nauki.

Elektrownia Jądrowa w Żarnowcu została zamknięta w trakcie budowy w 1990 roku w skutek nasilających się protestów po wybuchu w Czarnobylu. Elektrownia miała używać tej samej technologii nuklearnej.

Projekt składa się z wideoinstalacji oraz fotografii, które artystka dobiera i aranżuje odpowiednio do aktualnej przestrzeni wystawienniczej, tym razem - toruńskiej Wozowni.

\section{Urszula Kozak, kadry z Elektrowni Jądrowej w Zarnowcu} (fot. $\mathrm{z}$ archiwum autorki)

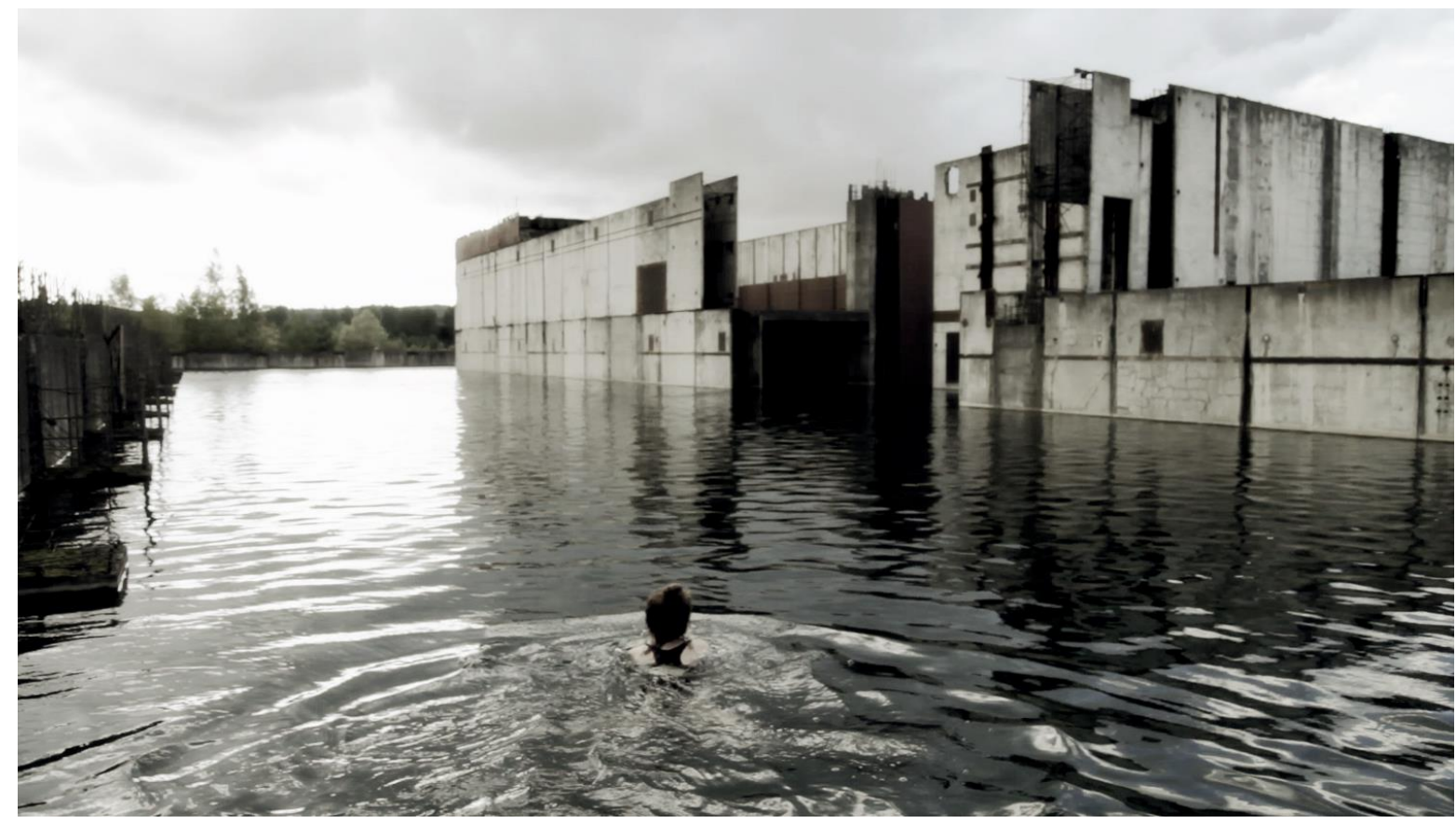



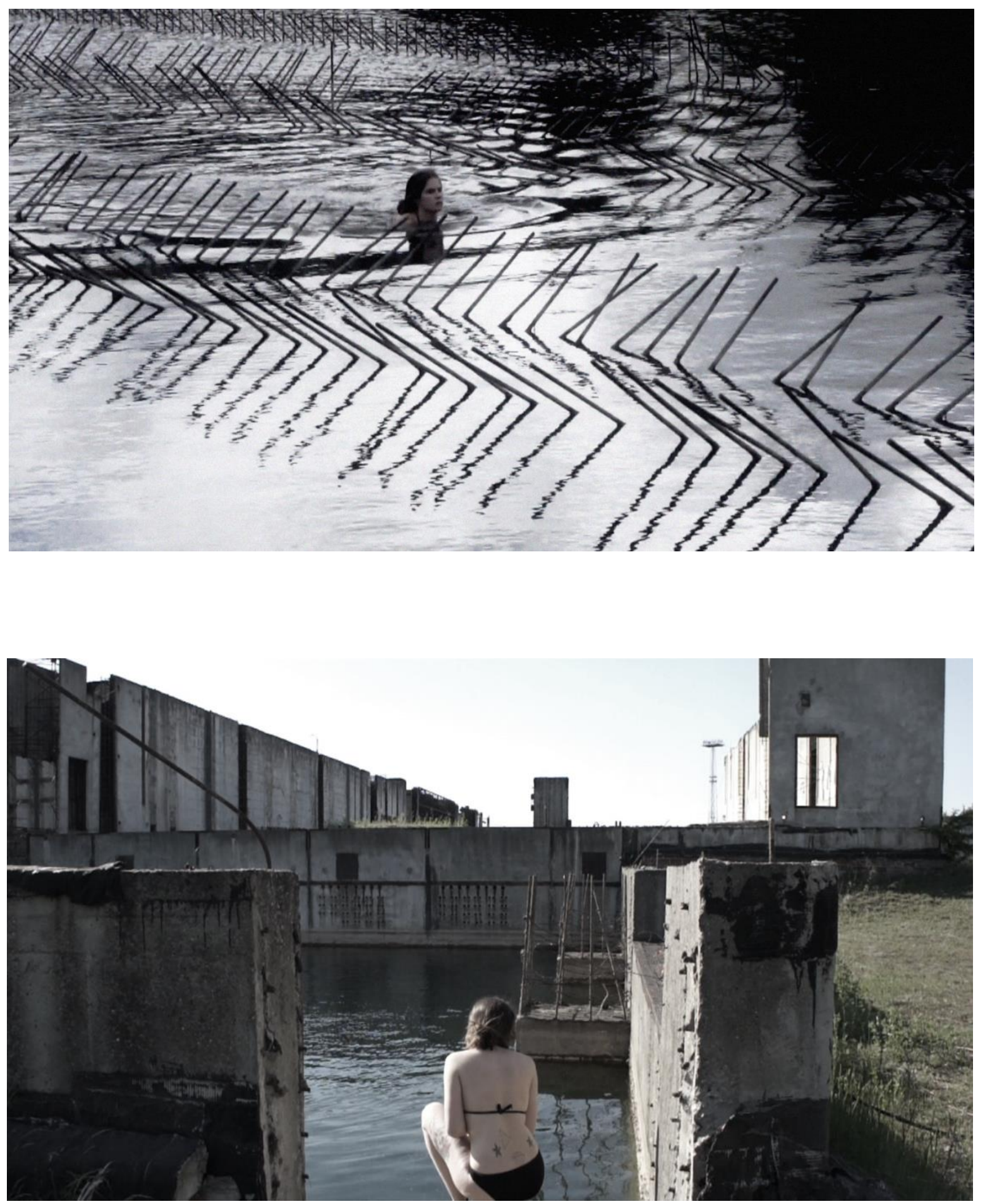


\section{Zofia Martin ${ }^{90}$ - Wesoła gromadka}

13.02 - 8.03.2015, Wozownia

Wesoła gromadka

Spojrzyjcie na dzieci

wesołe to stadko

co mamcia nazywa

wesołą gromadką

Są wszyscy przykładni, weseli, kochani, a na tym obrazku

dokładnie zebrani.

Jest Błażuś nieśmiały, lecz zawsze wesoły, Jest Hania co pilnie już chodzi do szkoły.

Nasz Błażuś to pieska, to kopnie w coś kotka bo zwykł kopać wszystko co tylko gdzie spotka,

A Hania w flaszeczkę nałapie znów muszek lub nóżkę podstawi, by upadł staruszek.

Jest w końcu i Kocio najmłodszy z tych dzieci, lecz który im także przykładem swym świeci:

To szybkę wybije strzelając gdzieś z procy, to domek podpali cichutko wśród nocy...

Mieć takie wesołe i miłe dzieciny to są jakby kwiaty dla całej rodziny. ${ }^{91}$

Zofia Martin, Węgorze z Wesolej gromadki
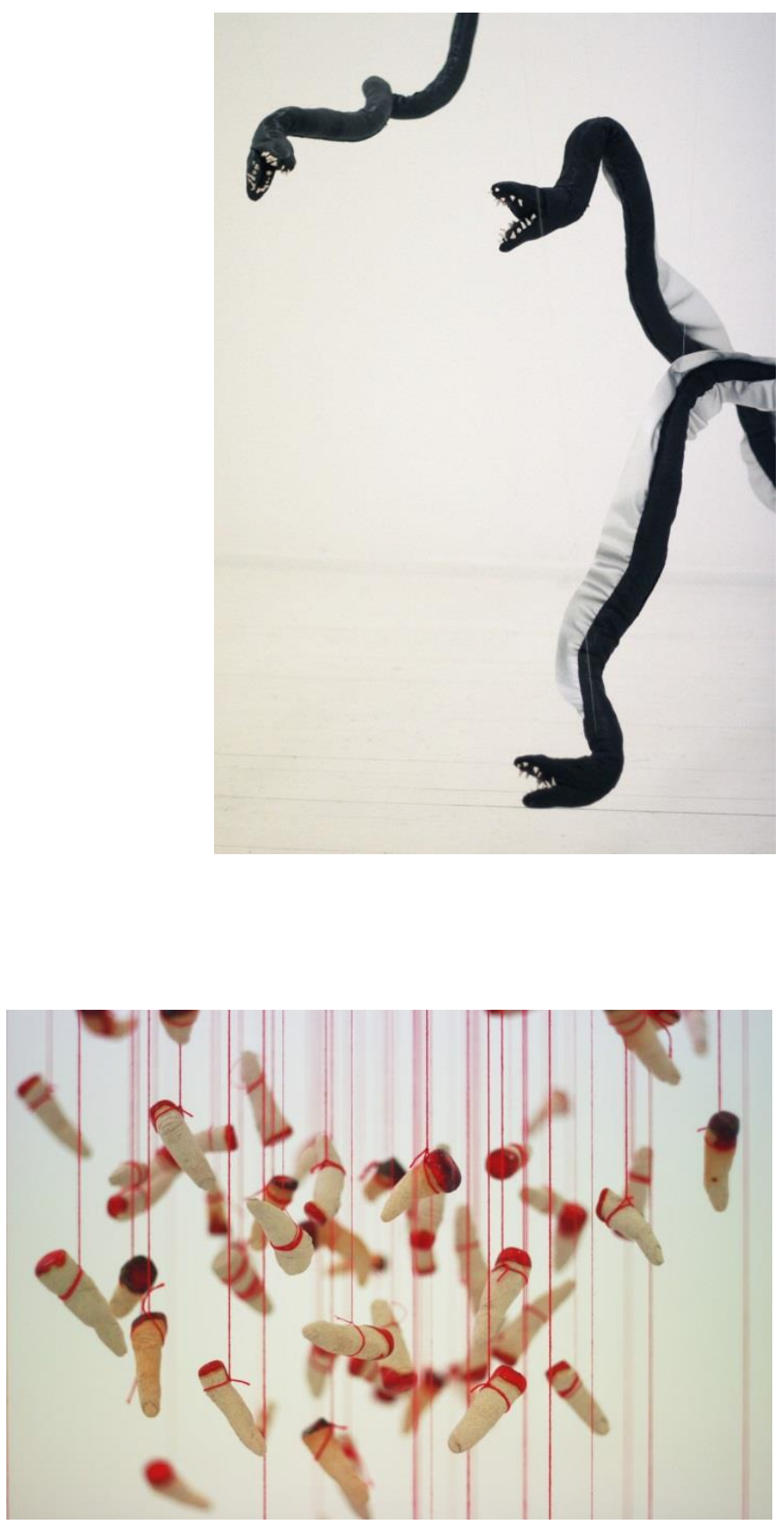

Zofia Martin, Ucięte paluszki z Wesołej gromadki

${ }^{90}$ Studiuje Intermedia na Akademii Sztuk Pięknych w Gdańsku.

${ }^{91}$ Źródło: URL = < http://www.wozownia.pl/exposureid357-4-Zofia_Martin_-_Wesola_gromadka>. 


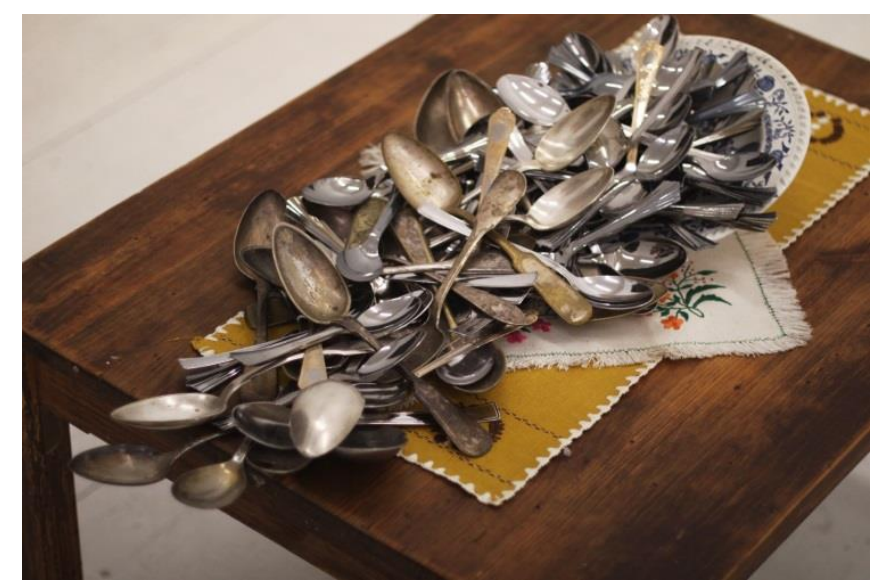

Zofia Martin, Łyżki z Wesolej gromadki

(fot. $\mathrm{z}$ archiwum autorki)

Zły sen, zmora, co przychodzi nocą i siada cicho na piersi, wpatrując się swoimi szklistymi oczami, krwawe opowieści śpiewane słodkim, dziecięcym głosem stanowią dla Zofii Martin początek historii nasiąkniętej krwią. Od pierwszego, wypowiedzianego słowa ta „zaiste” wesoła gromadka zmierza ku nieuniknionej śmierci - w bólu i cierpieniu. Perwersja, w której nieposłuszeństwo wobec pewnych kulturowych norm kończy się tragicznie dla ofiary. Rozczłonkowane ciało, okaleczone, krwawiące, martwe. Ale przecież jest to kara zawsze słuszna (?) i zawsze sprawiedliwa (?).

Zofia Martin wizualizuje trzy wierszydełka-straszydełka, które - pozbawione jakiejkolwiek metaforyki - wprost opisują przedziwne historyjki z życia dzieci. Opresyjne, sadystyczne konsekwencje nieposłuszeństwa stanowią wyrok dla tych ofiar - dzieci. Wiszące, ceramiczne, obcięte palce Juleczka, który bez przerwy je ssał, stos łyżek - przedmioty smutnego chłopca, co nie chciał jeść zupy, aż w końcu dnia szóstego zmarł, czy zębate, tłuste węgorze czekające na Zyzia, który pomimo ostrzeżeń dorosłych wszedł do głębokiej wody wprowadzają widza $\mathrm{w}$ przestrzeń pełną niepokoju i niepewności. I jeszcze te głosy, dziecięce, nachodzące na siebie, zapętlone, recytujące tę nadzwyczajną poezję. 


\section{Bibliografia}

Bachofen, J.J. 1993. Das Mutterrecht: eine Untersuchung uber die Gynaikokratie der AltenWelt nach ihrer religiosen und rechtlichen Natur. Frankfurt am Main.

Beauvoir de, S. 2003. Druga płeć. Przeł. M. Leśniewska i G. Mycielska. Warszawa: Czarna Owca.

Blackledge, C. 2005. Wagina. Kobieca seksualność w historii kultury. Przeł. Katarzyna Bartuzi. Warszawa: Prószyński i S-ka SA.

Cixous, H. 1993. Śmiech Meduzy. Przeł. A. Nasiłowska. Teksty Drugie nr 4/5/6.

Daly, M. 1973. Beyond God the Father. Toward a Philosophy of Women's Liberation. Boston: Beacon Press.

Davidson S. 1969. An 'Oppressed Majority' Demands its Rights. The Cause of Women's Equality Draws a Growing Number of Active-and Angry-female Militants. URL = $<$ http://www.maryellenmark.com/text/magazines/life/905W-000-004.html>, dostęp: 2.05.15.

Davis, E.G. 1971. The First Sex. New York: Penguin Books.

Firestone, S. 1971. The Dialectic of Sex. The Case for Feminist Revolution. London: Morrow Quill Paperbacks.

Furmanik, M. 2007. Kultury Azji oczami artystek. URL = <http://www.unigender.org/?page=biezacy\&issue=02\&article=05>, dostęp: 17.06.2015.

Fuss, D. 1989. Essentially Speaking: Feminism. Nature and Diffrence. New York-London.

Geshe Rabten. 1983. Sutra Doskonałej Mądrości. London: Echoes of Voidness.

Goethe, J.W. 2012. Faust. Przeł. Władysław Kościelski. Kraków: Greg.

Jakubowska, A. 2002. Na marginesach lustra. Ciało kobiece w pracach polskich artystek. Kraków: Universitas.

Jung, C. G. 1992. O naturze kobiety. Przeł. Magnus Starski. Poznań: Brama-Książnica Włóczęgów i Uczonych.

Jung, C. G. 1968. Collected Works. vol. 9. Princeton: Princeton University Press.

Kowalczyk, I. 2002. Ciało i władza. Polska sztuka krytyczna lat 90. Warszawa: Wydawnictwo Sic!

Lewandowska, K. 2014. Suki. Autoportret z kochanką. Manifest o wolności Liliany Piskorskiej. URL = <http://magazynsztuki.eu/index.php/teksty/126-suki-autoportretz-kochanka>, dostęp: 17.06.2015.

Menninghaus, W. 2009. Wstręt. Teoria i historia. Przeł. Grzegorz Sowiński. Kraków: Universitas: 415-440.

Millet, K. 1982. Teoria polityki ptciowej. Przeł. T. Hołówka, red. Nikt nie rodzi się kobietą: 58-111. Warszawa: Czytelnik. 
Samuel, A., Shorter, B. i Plaut, F. 1994. Krytyczny stownik analizy jungowskiej. Wrocław: Oficyna Wydawnicza UNUS.

Pindera, A. i Zielińska, J. Nie patrz prosto $w$ stońce 27.06-13.09.2009. Prace z kolekcji Daros Latinamerica. Katalog wystawy. Toruń: CSW.

\begin{abstract}
The article presents the works of Polish female artists belonging to the curatorial-artistic project FEMININE. It can be also called a kind of ongoing intervention. The first exhibition took place in 2011 in the gallery Wozownia in Torun and has continued since then. The cycle functions uninterrupted, deeply embedded in the concrete ideas closely related to the feminist art and the female experience entangled in the body, biology and emotions, already reworked in the artistic, cultural and social context. All artists invited to take part in FEMININE project have been carefully chosen for several important reasons. First of all, the decision has been made due to the subjective, individual choice and the aesthetic, ethical preferences of the curator. Secondly, it is also important that these talented artists - for various reasons - do not belong to the mainstream of the contemporary art.

The presentation of the exhibitions which follows has taken the form of short, personal impressions, created spontaneously after the first contact with the works. Hence, it is more of a notebook with important notations which can be treated as a first step towards deeper scientific analysis, yet to be done.
\end{abstract}

Keywords: Polish female artists, intervention, feminism, corporality, emotion 